\title{
Lactation Characteristics in Alpine and Nera di Verzasca Goats in Northern Italy: A Statistical Bayesian Approach
}

\author{
Stella Agradi ${ }^{1,+}{ }^{+}$, Alessia Libera Gazzonis ${ }^{1,+}{ }^{\circ}$, Giulio Curone ${ }^{1, *} \mathbb{C}$, Massimo Faustini ${ }^{1}$, Susanna Draghi ${ }^{1}$, \\ Gabriele Brecchia ${ }^{1}$, Daniele Vigo ${ }^{1}{ }^{\circledR}$, Maria Teresa Manfredi ${ }^{1}$, Sergio Aurelio Zanzani ${ }^{1}$ (D), Luisa Pulinas ${ }^{2}$, \\ Majlind Sulce $^{3}$, Albana Munga ${ }^{3}$, Marta Castrica ${ }^{4}{ }^{-}$and Laura Menchetti ${ }^{5}[$
}

check for

updates

Citation: Agradi, S.; Gazzonis, A.L.; Curone, G.; Faustini, M.; Draghi, S.;

Brecchia, G.; Vigo, D.; Manfredi, M.T.;

Zanzani, S.A.; Pulinas, L.; et al.

Lactation Characteristics in Alpine and Nera di Verzasca Goats in

Northern Italy: A Statistical Bayesian Approach. Appl. Sci. 2021, 11, 7235.

https://doi.org/10.3390/app11167235

Academic Editors: Alessandra Durazzo and Maria Kanellaki

Received: 4 July 2021

Accepted: 2 August 2021

Published: 5 August 2021

Publisher's Note: MDPI stays neutral with regard to jurisdictional claims in published maps and institutional affiliations.

Copyright: (c) 2021 by the authors. Licensee MDPI, Basel, Switzerland. This article is an open access article distributed under the terms and conditions of the Creative Commons Attribution (CC BY) license (https:// creativecommons.org/licenses/by/ $4.0 /)$
1 Department of Veterinary Medicine (DIMEVET), University of Milan, Via dell'Università 6, 26900 Lodi, Italy; stella.agradi@unimi.it (S.A.); Alessia.gazzonis@unimi.it (A.L.G.); Massimo.faustini@unimi.it (M.F.); Susanna.draghi@studenti.unimi.it (S.D.); Gabriele.brecchia@unimi.it (G.B.); daniele.vigo@unimi.it (D.V.); mariateresa.manfredi@unimi.it (M.T.M.); Sergio.zanzani@unimi.it (S.A.Z.)

2 Department of Veterinary Medicine of Sassari, University of Sassari, Via Vienna 2, 07100 Sassari, Italy; luisapulinas@hotmail.it

3 Faculty of Veterinary Medicine, Agricultural University of Albania, Rr Paisi Vodica, Koder, 1029 Kamez, Albania; msulce@ubt.edu.al (M.S.); amunga@ubt.edu.al (A.M.)

4 Department of Health, Animal Science and Food Safety "Carlo Cantoni”, Università degli Studi di Milano, Via Celoria 10, 20133 Milan, Italy; marta.castrica@unimi.it

5 Department of Agricultural and Agri-food Sciences and Technologies, University of Bologna, Viale Fanin 46, 40138 Bologna, Italy; laura.menchetti@unibo.it

* Correspondence: giulio.curone@unimi.it; Tel.: +39-02-50334756

$+\quad$ These authors contribute equally to this work.

Abstract: In the last three decades, we assisted in a shift in the dairy product preferences in developed countries, with an increase in goat-derived products consumption. As already seen in the bovine sector, the diffusion of goat milk consumption has led to an abandonment of the local breeds in favor of the more productive cosmopolitan breeds, with an intense reduction in the livestock biodiversity. However, in several studies, it has been shown that local breeds present unique features such as a robust behavior towards the local climate and a high quality of their dairy products. This study aims to assess the differences between the basic lactation variables (milk yield, fat $\%$, protein $\%$, lactose $\%$ and somatic cell count) in the Alpine goat and the local breed Verzasca goat from a Bayesian point of observation. Results indicate that the Nera di Verzasca goat has overall lactation characteristics similar toa cosmopolite breed such as the Alpine goat, except for the milk daily yield reduced with respect to Alpine goats ( $1.68 \pm 0.84$ and $2.14 \pm 1.03$, respectively). Moreover, the Verzasca goat showed a tendency to maintain a lower level of somatic cell count along with lactation $(798 \pm 1734$ and $1216 \pm 2828$, respectively). These findings help to increase the knowledge about the Italian local goat breeds and are important in the optic of biodiversity conservation.

Keywords: goat; local breed; milk; Alpine goat; Verzasca goat

\section{Introduction}

Goat (Capra hircus, L.) has been, along with sheep (Ovis aries, L.), the first species to be domesticated by humankind about 11,000 years ago [1]. During contemporary history, the world goat population has been constantly increasing. In particular, starting from 1990, it has risen from about 600 million to over one billion in 2019 [2]. The world production of goat-derived products has shown a positive trend in the last three decades [2]. That trend could be attributed to a shift in food preferences in developed countries [3] and to the increase in semi-desertic areas with impossibility to raise grazer animals, rather than browser, in underdeveloped and developing countries [4]. India and China are the countries with the highest number of these animals, followed by different African and Asian smaller nations, and are, respectively, the world's largest producers of goat milk and 
meat [2]. However, it is likely that goat meat and, in particular, milk productions data from FAO are underestimates of real values, being that in many countries there is a traditional local production for home consumption that is not reported in the official statistics.

Differences in chemical composition between cow milk and goat milk have been deeply investigated [5]. Several health benefits (scientifically proved or not) to people associated to goat milk are in likelihood to be one of the reasons for its increased consumption. In particular, it is believed that goat milk has lower allergenic properties when compared to cow milk. For that reason, it is usually used as a substitute of cow milk in children with a milk allergy [6]. However, it has been pointed out that the hypoallergenic characteristic of goat dairy products depends on the concentration of $\alpha_{s 1}$-casein. That, in turn, depends on the wide variety of genetic polymorphisms of this casein protein [7].

In Italy, goat milk production has been constantly increasing in recent decades, achieving nearly 450,000 quintals in 2019 [8]. However, in the peninsula, it represents a lower production among the main dairy domesticated species (cow, sheep and buffalo) [8]. The diffusion of goat milk consumption, as in the dairy cattle sector, led to a flattening in the genetic characteristics of cosmopolitan goat breeds, which are mainly used for milk production $[9,10]$. In Italy, the knowledge about local goat breeds is sparse and rare in scientific literature [11-18]. The few studies that have been conducted were mainly focused on the comparison of dairy products' quali-quantitative characteristics in different Mediterranean autochthonous goat breeds versus Saanen, Alpine and Maltese goats. The studies have highlighted a higher milk yield of the cosmopolitan breeds, but a lower milk nutritional quality [12-17]. Additionally, the coagulative aptitude and nutritional value of cheeses were higher in the Mediterranean breeds [13,17,19], and the colostrum from Garganica goats versus Saanen or Maltese has shown interesting oligosaccharides concentrations [11,18].

Alpine goat (Camosciata delle Alpi) is a dairy breed. It is originally from the mountainous cantons of Bern, Freiburg, Glarus and Graubünden in Switzerland. However, in recent decades, it has been exported in several other countries such as France, Italy and Germany, but it is also reared outside Europe. In Italy, it is mainly found in the Alpine regions, especially in Piedmont and Trentino-Alto Adige. The numerosity in 2020 was of 67,780 heads in the National Zootechnical Register. This breed is a medium-large size goat, originally sturdy, strong, well-adapted to the climate and mountainous geographical conditions. However, the selection for milk production has led to a weakening of its rusticity characteristics.

The Verzasca (Nera di Verzasca or Verzaschese) is a double aptitude breed. It is originally from the Verzasca Valley, in the canton of Ticino in Southern Switzerland. In Italy, it is mainly reared in the provinces of Como, Varese and Verbano-Cusio-Ossola in Northern Lombardy and Piedmont. The numerosity in 2020 was of 2248 heads in the National Zootechnical Register. It is also a medium-large size goat and is characterized by a high rusticity and resistance both to high and low temperatures. In Italy, it is considered an autochthonous breed of limited distribution among the forty-six for which the national association of pastoralism (AssoNaPa) keeps a herd book.

The aim of the present paper is to assess the differences between the basic lactation variables in Alpine and Verzasca goats from a Bayesian point of observation.

\section{Materials and Methods}

\subsection{Animals}

For this study, 71 female goats were selected. They were of Alpine $(n=37)$ and Verzasca $(n=34)$ breed and managed under the same semi-extensive farming system in the mountains near Verbano Lake, in Varese province, Northern Italy. The farm was located at $980 \mathrm{~m}$ above sea level (m.s.l.), but goats were kept under indoor housing at that altitude only during winter, when they were fed hay ad libitum with an increasing supplementation of concentrate from the dry period to early lactation (from $300 \mathrm{~g} /$ day to $600 \mathrm{~g} /$ day). From March to November, the goats were free to graze on alpine pasture nearby the housing (200 hectares (ha) between 900 and 1550 m.s.l.). The diet was based 
on the vegetable essences typical of that area, as described by Maggioni et al. [20]. Birth season was from 11th of January to the 21st of March, and since parturition goats were milked twice a day until September.

Only clinically healthy goats that had eutocic delivery and regular post-partum were included in the study. The mean rectal temperature ranged between 38.5 and $39.7^{\circ} \mathrm{C}$. Mean Body Condition Score (BCS) was 2.8 for Alpine goats, 2.7 for Verzasca ones. Mean age was $4.21 \pm 2.27$ for Alpine goats and $4.79 \pm 2.34$ for Verzasca goats.

In order to evaluate the effects of age and days in milk (DIM) on response variables, a subdivision in classes was performed. The age of goats was expressed as age class:

Class 1-1 to 2.9 years

Class 2-3 to 4.9 years

Class 3-5+ years

Similarly, the DIM of goats were subdivided in:

\author{
Class 1-0 to 30 DIM \\ Class 2-31 to 50 DIM \\ Class 3-51 to 100 DIM \\ Class 4-101 to 150 DIM \\ Class 5-150 + DIM
}

\title{
2.2. Sample Collection and Analysis
}

Milk samples were monthly collected from February to September and analyzed by the Milk Standard Laboratory of the Italian Breeder Association (A.I.A.). Individual milk yield was collected at the official Milk Recording [21]. A total of 121 milk collections were performed on Alpine goats, and 170 samplings were performed on Verzasca subjects. The milk was obtained from hand milking before morning milking. First streams of foremilk were discharged and milk was collected in Corning ${ }^{\mathrm{TM}}$ Falcon $15 \mathrm{~mL}$ conical centrifuge tubes. The samples were immediately refrigerated and sent to the laboratory in $12 \mathrm{~h}$, where they were analyzed in duplicate.

The distribution of the milk collections in terms of age class and DIM class are reported in Table 1.

Fat, protein and lactose percentage were determined by infrared method (Laboratorio Standard Latte-Associazione Italiana Allevatori (LSL-AIA) http:/ / www.aia.it/lsl/index. $\mathrm{htm}$, accessed on 5 April 2021). The somatic cell count (SCC) was determined by fluoroopto-electronic counting (Bentley SOMACOUNT 150, Bentley Instruments, Chaska, MN, USA) and was expressed as $\log _{10}$ SCC.

Moreover, the fat/protein and the fat/lactose ratios were calculated on raw data, since fat/protein and fat/lactose ratios in milk are valuable lipomobilization indexes in cows, as well as indexes of pathologies and post-partum disorders [22,23].

\subsection{Statistical Data Analysis}

On raw data, the univariate descriptive statistics (mean and standard deviation) were calculated. To assess the effects of breed, age and lactation period, a Bayesian approach to ANOVA was adopted. Bayes' ANOVA analysis is essentially based on the evaluation of one or more effects given a prior probability of an outcome. ANOVA Bayesian analysis was performed with the software jamovi for Windows. The significance (strength) of posterior probabilities was derived from the Jeffreys classification of Bayes Factor (BF10) or, otherwise, the inverse (BF01) [24]. A notation similar to the frequentist statistics results was adopted, following the Jeffreys' suggestions, resumed in Table 2. 
Table 1. Sample distributions for breed, age class and days in milk class (DIM class) for the enrolled goats.

\begin{tabular}{|c|c|c|}
\hline Breed & Age Class (Years) & $n$ \\
\hline \multirow{3}{*}{ Alpine } & $1-2.9$ & 45 \\
\hline & $3-4.9$ & 21 \\
\hline & $5+$ & 55 \\
\hline \multirow{3}{*}{ Verzasca } & $1-2.9$ & 35 \\
\hline & $3-4.9$ & 78 \\
\hline & $5+$ & 57 \\
\hline \multicolumn{3}{|c|}{ DIM class (days) } \\
\hline \multirow{5}{*}{ Alpine } & $0-30$ & 9 \\
\hline & $31-50$ & 20 \\
\hline & 51-100 & 24 \\
\hline & $101-150$ & 37 \\
\hline & $150+$ & 31 \\
\hline \multirow{5}{*}{ Verzasca } & $0-30$ & 7 \\
\hline & $31-50$ & 27 \\
\hline & $51-100$ & 33 \\
\hline & 101-150 & 46 \\
\hline & $150+$ & 57 \\
\hline
\end{tabular}

Table 2. BF10, inverse BF10 [24] and arbitrary significance asterisks, inserted by authors.

\begin{tabular}{cccc}
\hline Evaluation & BF10 & Inverse BF10 & Significance \\
\hline Anecdotal & $1-3$ & $1-0.33$ & $\mathrm{~ns}$ \\
Substantial & $3-10$ & $0.33-0.1$ & $\mathrm{~ns}$ \\
Strong & $10-30$ & $0.1-0.03$ & $*$ \\
Very strong & $30-100$ & $0.03-0.01$ & $* *$ \\
Decisive & $>100$ & $<0.01$ & $*$
\end{tabular}

The different asterisks indicate different levels of statistical significance: strong $\left({ }^{*}\right)$, very strong $\left({ }^{* *}\right)$, decisive $\left(^{* * *}\right)$.

The notation with asterisks was chosen arbitrarily by authors considering the strength of evidence.

Data were processed for univariate descriptive analysis: mean value and standard deviation were considered for data summarization. The effects of breed, age class and days in milk class on response variables were analyzed by the Bayesian ANOVA analysis procedure (Jamovi ver. 1.1.7.0. for Windows). The model analyzed was resumed in the following relation:

$$
\text { Output variable }_{i j k l}=\mu+\text { breed }_{i}+\operatorname{age}_{j}+D I M_{k}+\varepsilon_{i j k l}
$$

where:

$\mu=$ grand mean

breed $=$ fixed factor for breed

age $=$ fixed factor for age class

$D I M=$ fixed factor for days in milk class

$\varepsilon=$ error

The breeds differences on age class and DIM classes were based on the interaction between factors. 
Moreover, the Bayesian correlation coefficients between variables in each breed were calculated.

\section{Results}

The summary descriptive statistics expressed as mean \pm standard deviation are reported in Table 3.

Table 3. Descriptive statistics for milk parameters in Alpine and Nera Verzasca goats.

\begin{tabular}{|c|c|c|c|c|c|c|}
\hline & Breed & $\begin{array}{c}\text { Milk Yield } \\
\text { (1/d) }\end{array}$ & Fat $(\%)$ & Protein (\%) & Lactose $(\%)$ & $\operatorname{SCC}^{1}\left(10^{3} / \mathrm{mL}^{2}\right)$ \\
\hline \multirow{2}{*}{ Mean $\pm \mathrm{SD}^{2}$} & Alpine & $2.14 \pm 1.03$ & $3.18 \pm 0.78$ & $3.15 \pm 0.39$ & $4.43 \pm 0.28$ & $1216 \pm 2828$ \\
\hline & Verzasca & $1.68 \pm 0.84$ & $3.27 \pm 0.82$ & $3.24 \pm 0.41$ & $4.55 \pm 0.26$ & $798 \pm 1734$ \\
\hline \multirow{2}{*}{ Min - Max } & Alpine & $0.10-5.20$ & $1.23-4.62$ & $2.27-4.46$ & $3.62-5.05$ & $48-27,987$ \\
\hline & Verzasca & $0.10-4.00$ & $1.52-4.78$ & $2.48-4.77$ & $3.66-5.14$ & $27-17,311$ \\
\hline
\end{tabular}

${ }^{1}$ SCC—somatic cell count; ${ }^{2}$ SD—standard deviation.

The effects of breed, age class and DIM class on milk yield are reported in Table 4. The Bayesian analysis put in evidence a significant effect of breed and DIM: Alpine goats yielded a higher amounts of milk in a single milking than Nera Verzasca, when age class or DIM class were considered (Table 4 and Figure 1a,b). In both breeds, daily milk yield reached a zenith in the period 51-100 DIM, more evident in Alpine goats than Verzasca ones. Then, the milk yield progressively decreased, reaching values significantly lower than the ones at the beginning of lactation. Although milk fat and protein percentages did not differ between breeds, a decreasing trend in fat and protein percentage was observable during aging (statistically significant only for protein percentage) (Table 4 and Figure 1c,d); both the milk fat percentage and milk protein percentage had shown a " $U$ " shape trend when considering DIM classes (Figure 1e,f). These two parameters, in fact, assumed their higher values at the beginning and at the end of lactation; while in the middle of it, they reached the lowest values. Milk lactose percentage was significantly higher in the Nera Verzasca than in the Alpine breed. This difference was maintained during all the lactation periods considered and maintained a constant, decreasing trend (Table 4 and Figure 1g,h). The fat/protein ratio in milk, as a fat mobilization index, changed significantly with DIM (Figure 1j), without evidencing differences between breeds or age class (Figure 1i). The fat/lactose ratio as a secondary fat mobilization index statistically overlapped to the fat/protein ratio, with significant influence of DIM class (Table 4 and Figure 11). Somatic cell count (SCC) significantly increased both with age and DIM class, but no statistically significant differences were shown between breeds, although a higher value in SCC was observed in the Alpine breed milk (Tables 3 and 4 and Figure 1m,n).

Tables 5 and 6 show the Bayesian correlation coefficients between milk variables in the two examined breeds. Correlations appeared similar between breeds, except for milk yield that differently correlated with some variables in different fashions if the Alpine or Nera Verzasca breed was considered. Milk fat percentage was strongly negatively correlated with milk yield, but this correlation was stronger in the Alpine than in the Nera Verzasca breed (Table 5). Analogue conclusions can be drawn for the fat/protein ratio (Table 5). An opposite behavior could be seen considering the milk yield and protein percentage (Table 5), with a stronger negative correlation in the Nera Verzasca breed with respect to the Alpine goat. 
Table 4. Bayesian ANOVA results for milk variables. Significance symbols were derived from the BF10 values as reported in the text. The different asterisks indicate different levels of statistical significance: very strong $\left({ }^{* *}\right)$, decisive $\left({ }^{* * *}\right)$.

\begin{tabular}{|c|c|c|c|c|}
\hline \multicolumn{5}{|c|}{ Milk Yield (1/Day) } \\
\hline Models & $\mathrm{P}(\mathrm{M})$ & $\mathrm{P}(\mathrm{M} \mid$ data $)$ & BF10 & Signif \\
\hline Breed & 0.0769 & $3.53 \times 10^{-30}$ & 503.38 & $* * *$ \\
\hline Age class & 0.0769 & $3.88 \times 10^{-32}$ & 5.54 & $* *$ \\
\hline DIM $^{2}$ class & 0.0769 & $2.01 \times 10^{-8}$ & $2.86 \times 10^{24}$ & $* * *$ \\
\hline \multicolumn{5}{|c|}{ Fat $(\%)$} \\
\hline Breed & 0.0769 & $5.29 \times 10^{-8}$ & 0.19 & Ns \\
\hline Age class & 0.0769 & $4.53 \times 10^{-7}$ & 1.64 & Ns \\
\hline DIM $^{2}$ class & 0.0769 & 0.31 & $1.11 \times 10^{6}$ & $* * *$ \\
\hline \multicolumn{5}{|c|}{ Protein (\%) } \\
\hline Breed & 0.0769 & $2.34 \times 10^{-11}$ & 0.66 & Ns \\
\hline Age class & 0.0769 & $3.22 \times 10^{-9}$ & 90.83 & $* *$ \\
\hline DIM $^{2}$ class & 0.0769 & 0.01 & $4.37 \times 10^{7}$ & $* * *$ \\
\hline \multicolumn{5}{|c|}{ Lactose (\%) } \\
\hline Breed & 0.0769 & $4.31 \times 10^{-31}$ & 170.17 & $* * *$ \\
\hline Age class & 0.0769 & $4.19 \times 10^{-33}$ & 1.65 & Ns \\
\hline DIM $^{2}$ class & 0.0769 & $1.24 \times 10^{-7}$ & $4.91 \times 10^{25}$ & $* * *$ \\
\hline \multicolumn{5}{|c|}{ Fat/Protein } \\
\hline Breed & 0.0769 & $6.75 \times 10^{-10}$ & 0.13 & Ns \\
\hline Age class & 0.0769 & $4.52 \times 10^{-10}$ & 0.09 & Ns \\
\hline DIM $^{2}$ class & 0.0769 & 0.81 & $1.56 \times 10^{8}$ & $* * *$ \\
\hline \multicolumn{5}{|c|}{ Fat/Lactose } \\
\hline Breed & 0.0769 & $9.09 \times 10^{-5}$ & 0.13 & Ns \\
\hline Age class & 0.0769 & $3.39 \times 10^{-4}$ & 0.49 & Ns \\
\hline DIM $^{2}$ class & 0.0769 & 0.55 & 785.59 & $* * *$ \\
\hline \multicolumn{5}{|c|}{$\log _{10} \mathrm{SCC}^{1}$} \\
\hline Breed & 0.0769 & $3.63 \times 10^{-9}$ & 2.85 & Ns \\
\hline Age class & 0.0769 & $9.47 \times 10^{-7}$ & 744.22 & $* * *$ \\
\hline DIM $^{2}$ class & 0.0769 & $1.20 \times 10^{-4}$ & $94,248.97$ & $* * *$ \\
\hline
\end{tabular}

${ }^{1}$ SCC—-somatic cell count; ${ }^{2}$ SD—standard deviation.

Table 5. Bayesian correlation coefficients for milk variables in Alpine goat breed. Asterisks evidence the significance of $\mathrm{BF}_{10}$ as reported in the text.

\begin{tabular}{|c|c|c|c|c|c|c|c|c|}
\hline & $\mathrm{BF}_{10}$ & Milk Yield & Fat & Protein & Lactose & F/P ${ }^{2}$ Ratio & F/L ${ }^{3}$ Ratio & $\log _{10} S_{C C} 1$ \\
\hline \multirow{2}{*}{ Milk Yield } & $\mathrm{r}$ & - & & & & & & \\
\hline & $\mathrm{BF}_{10}$ & - & & & & & & \\
\hline \multirow{2}{*}{ Fat } & $\mathrm{r}$ & -0.41 & - & & & & & \\
\hline & $\mathrm{BF}_{10}$ & $* * *$ & - & & & & & \\
\hline \multirow{2}{*}{ Protein } & $\mathrm{r}$ & -0.31 & 0.29 & - & & & & \\
\hline & $\mathrm{BF}_{10}$ & $* *$ & * & - & & & & \\
\hline \multirow{2}{*}{ Lactose } & $\mathrm{r}$ & 0.17 & 0.41 & 0.02 & - & & & \\
\hline & $\mathrm{BF}_{10}$ & * & $* * *$ & * & - & & & \\
\hline \multirow{2}{*}{ F/P $\mathbf{P}^{2}$ Ratio } & $\mathrm{r}$ & -0.28 & 0.88 & -0.18 & 0.38 & - & & \\
\hline & $\mathrm{BF}_{10}$ & $*$ & $* * *$ & ns & $* * *$ & - & & \\
\hline \multirow{2}{*}{ F/L ${ }^{3}$ Ratio } & $\mathrm{r}$ & -0.49 & 0.97 & 0.31 & 0.17 & 0.85 & - & \\
\hline & $\mathrm{BF}_{10}$ & $* * *$ & $* * *$ & $* *$ & ns & $* * *$ & - & \\
\hline \multirow{2}{*}{$\log _{10} \mathrm{SCC}^{1}$} & $\mathrm{r}$ & -0.41 & 0.21 & 0.27 & -0.49 & 0.12 & 0.3 & - \\
\hline & $\mathrm{BF}_{10}$ & $* * *$ & ns & ns & $* * *$ & ns & $* * *$ & - \\
\hline
\end{tabular}

${ }^{1}$ SCC—-somatic cell count; ${ }^{2} \mathrm{~F} / \mathrm{P}$ ratio-fat to protein ratio; ${ }^{3} \mathrm{~F} / \mathrm{L}$ ratio-fat to lactose ratio. The different asterisks indicate different levels of statistical significance: strong $(*)$, very strong $\left({ }^{(*}\right)$, decisive $\left(^{(* *}\right)$. 

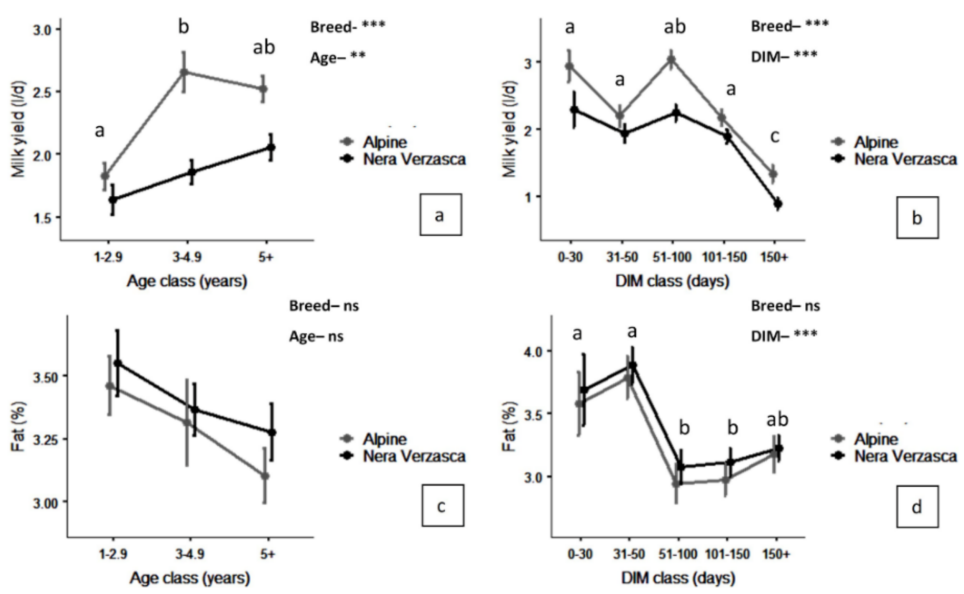

- Appine
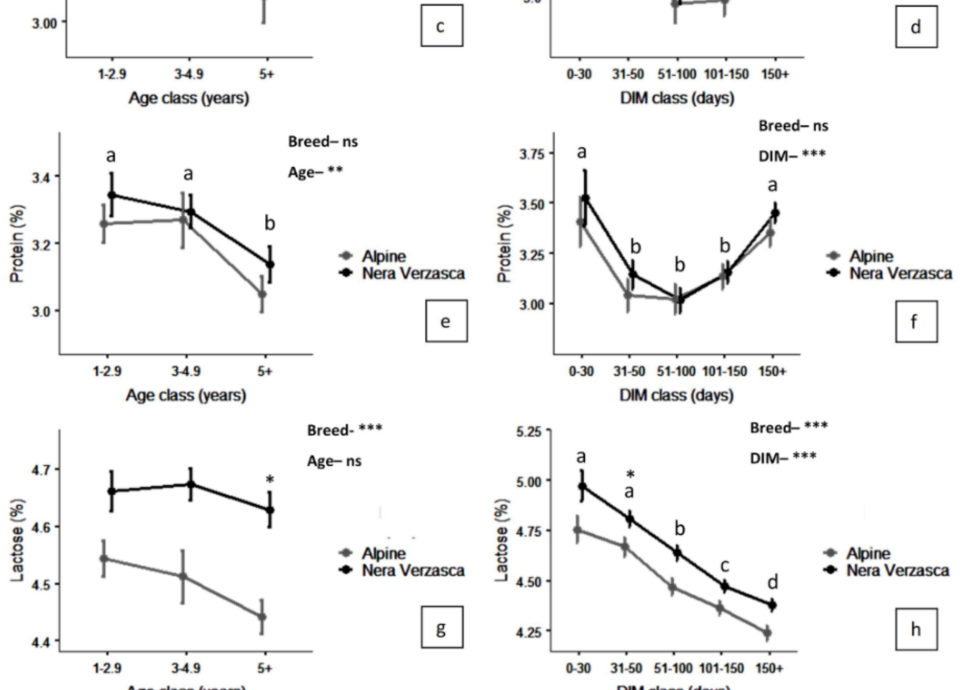

Alpine
Nera Verzasca
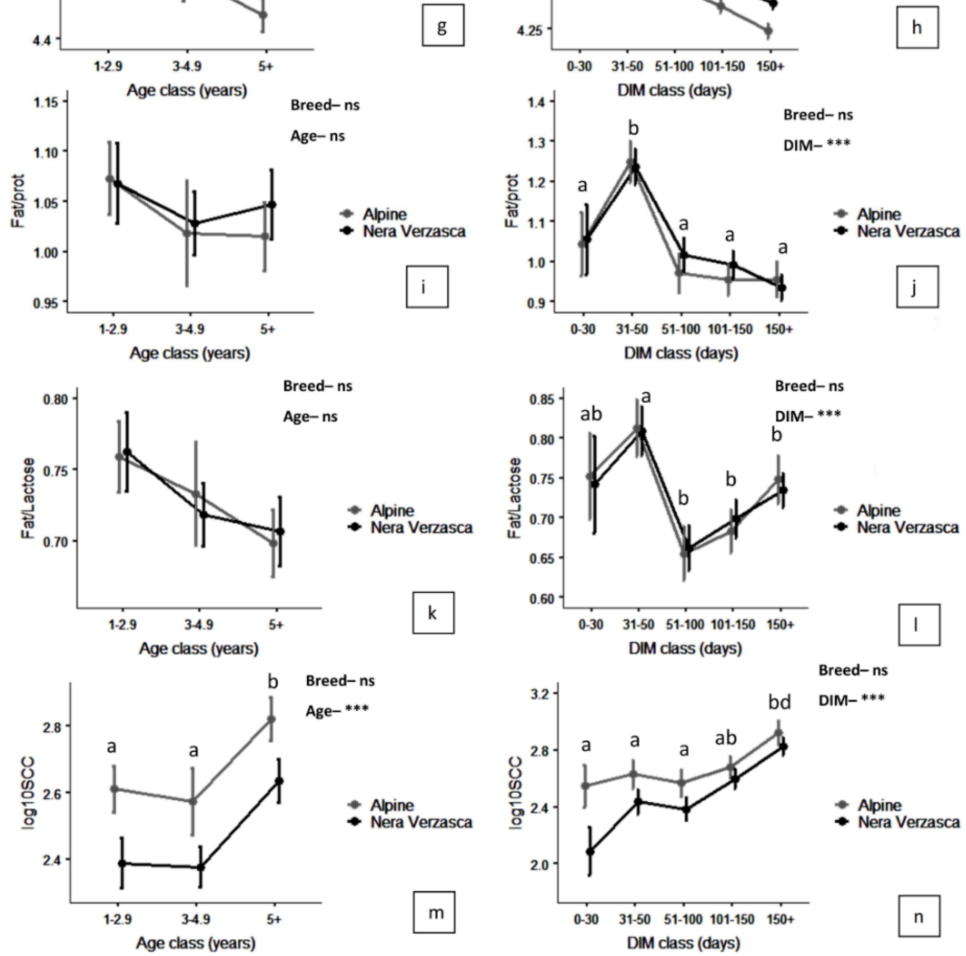

- Nera Verzasca

Figure 1. Patterns of milk variables in Alpine and Nera di Verzasca goat breeds for age and days in milk (DIM), respectively. The effects of breed, age and DIM have been evaluated on milk yield $(\mathbf{a}, \mathbf{b})$, milk fat \% (c,d), milk protein \% (e,f), milk lactose $\%(\mathbf{g}, \mathbf{h})$, milk fat/protein ratio (i,j), milk fat/lactose ratio $(\mathbf{k}, \mathbf{l})$ and on somatic cell count $(\mathbf{m}, \mathbf{n})$. Letters indicate a significant difference in age or DIM groups. Asterisks in the graphs indicate the age/DIM period with significant differences between breeds. Data were resumed as mean values and standard error of mean. 
Table 6. Bayesian correlation coefficients for milk variables in Nera di Verzasca goat breed. Asterisks evidence the significance of $\mathrm{BF}_{10}$ as reported in the text.

\begin{tabular}{|c|c|c|c|c|c|c|c|c|}
\hline & $\mathrm{BF}_{10}$ & Milk Yield & Fat & Protein & Lactose & F/P ${ }^{2}$ Ratio & F/L ${ }^{3}$ Ratio & $\log _{10} \mathrm{SCC}^{1}$ \\
\hline \multirow{2}{*}{ Milk Yield } & $\mathrm{r}$ & - & & & & & & \\
\hline & $\mathrm{BF}_{10}$ & - & & & & & & \\
\hline \multirow{2}{*}{ Fat } & $\mathrm{r}$ & -0.34 & - & & & & & \\
\hline & $\mathrm{BF}_{10}$ & $* * *$ & 一 & & & & & \\
\hline \multirow{2}{*}{ Protein } & $\mathrm{r}$ & -0.42 & 0.33 & - & & & & \\
\hline & $\mathrm{BF}_{10}$ & $* * *$ & $* * *$ & - & & & & \\
\hline \multirow{2}{*}{ Lactose } & $\mathrm{r}$ & 0.24 & 0.39 & 0.07 & - & & & \\
\hline & $\mathrm{BF}_{10}$ & $*$ & $* * *$ & Ns & - & & & \\
\hline \multirow{2}{*}{ F/P ${ }^{2}$ Ratio } & $\mathrm{r}$ & -0.16 & 0.88 & -0.15 & 0.37 & - & & \\
\hline & $\mathrm{BF}_{10}$ & * & $* * *$ & Ns & $* * *$ & 一 & & \\
\hline \multirow{2}{*}{ F/L ${ }^{3}$ Ratio } & $\mathrm{r}$ & -0.42 & 0.97 & 0.34 & 0.17 & 0.85 & - & \\
\hline & $\mathrm{BF}_{10}$ & $* * *$ & $* * *$ & $* * *$ & Ns & $* * *$ & - & \\
\hline \multirow{2}{*}{$\log _{10} \mathrm{SCC}^{1}$} & $\mathrm{r}$ & -0.43 & 0.16 & 0.23 & -0.32 & 0.07 & 0.25 & - \\
\hline & $\mathrm{BF}_{10}$ & $* * *$ & * & ns & $* * *$ & $*$ & $*$ & - \\
\hline
\end{tabular}

${ }^{1}$ SCC—-somatic cell count; ${ }^{2} \mathrm{~F} / \mathrm{P}$ ratio-fat to protein ratio; ${ }^{3} \mathrm{~F} / \mathrm{L}$ ratio-fat to lactose ratio. The different asterisks indicate different levels of statistical significance: strong $(*)$, decisive $\left({ }^{* * *}\right)$.

\section{Discussion}

Goat milk components are subject, as in other species, to a plethora of influencing factors, either biological or management factors, as evidenced by Sandrucci et al. [9]. It is, therefore, difficult to isolate these aspects in order to have a complete picture of the multiple interactions between factors.

The present paper evidenced and compared the characteristics of lactation in a local Italian/Southern Switzerland goat breed (Nera Verzasca) and a cosmopolite breed as the Alpine goat, both reared in the same farm; thus, with the same management conditions. These results can help to characterize and to protect this rare, endangered, local goat breed.

Currò et al. report, on research regarding local goat breeds, a significant influence of DIM on lactation traits [12]; the local breeds' milk yield was lower than cosmopolite breeds', but accounted for a reduced number of SCC and higher lactose. These features overlap with our experimental data: Nera Verzasca goats had a reduced milk yield with respect to the Alpine breed, but the SCC showed a tendency to be lower in the local Nera Verzasca breed. It must be highlighted that milk protein concentration was similar between breeds; this feature can be advantageous for Nera Verzasca goats when milk is considered for cheesemaking.

The average daily milk yield in our Alpine subjects appeared similar to the values reported for Alpine goats by Zeng et al. [25] (2.14 kg/day vs. $1.98 \mathrm{~kg} /$ day in our data and Zeng et al., respectively). However, this study was carried out in 1995 and just on primiparous goats. Another study conducted in Italy in 2018 which considered a different type of farming system, including an intensive one, recorded a daily mean yield of $2.57 \mathrm{~kg}$ for the Alpine goat [17]. That higher value could be explained both by different farm management systems (mainly referring to the diet) and the more than 20 years of progress made in the artificial selection for production traits. Similar values were also obtained in recent studies conducted in Croatia on Alpine goats [26,27]. On the other side, Verzasca goats showed an average milk yield of $1.68 \mathrm{~kg} /$ day in our study. That is an expected result, as stated above, because that breed was not strictly selected as in the case of the Alpine goat for milk production, but was actually a double aptitude breed. The effect of parity (i.e., age) shown in our study was in agreement with other previous investigations $[25,26,28,29]$ which highlighted a common trend: the first three lactations are characterized by a lower milk production compared to the 4th and 5th lactations, and are followed then by a decrease in the milk yield. This trend is the result of an increasing udder volume through lactations 
given by the progressive sum of new and old secretory parenchyma at every parturition. However, achieving the age of 5 years old, the organism probably has a reduction in performance. In our study, goats, considering the DIM class, reached a production peak during 51-100 days in milk after a slight depression during the period of 31-50 days of lactation. The same pattern, but with a reduced yield, was followed by the Nera Verzasca breed. This trend through lactation was perfectly confident with what was already present in the scientific literature [25,30], with a progressive increase in the milk yield starting from parturition till achieving a peak about 1 to 3 months post-partum. Then, a gradual decreasing pattern was shown until dry off.

Fat percentage was 3.18\% in Alpine and 3.27\% in Verzasca goats, not showing a statistically significant difference among breeds. The trend through lactation, with maximum values at the beginning and at the end of it, was likely due to a dilution effect given that caused both the fat and protein percentage to decrease during the higher lactational productive period $[25,26,31]$.

Even the protein percentage showed no differences between breeds and the same trend through lactation as the fat percentage. However, a significant age effect was also highlighted. The decreasing protein percentage with the increase in age was in agreement with the study of Antunac et al. [31].

The lactose percentage was the only parameter along with milk yield that showed a statistically significant difference between breeds. In particular, Verzasca goats showed a significantly higher value than the Alpine ones. Additionally, lactose showed a decreasing pattern starting from 30 to 50 days post-partum. That result has already been described in the literature $[25,31]$.

SCC was lower but not in a significant way in Verzasca goats $\left(798 \times 10^{3} / \mathrm{mL}\right)$ than in the Alpine ones $\left(1216 \times 10^{3} / \mathrm{mL}\right)$. In goats it is well documented that increasing the DIM was among the most important factors contributing to an increased cell count in the absence of intramammary infection [32,33]. In the present experiment, SCC exhibited a constant increase during DIM; moreover, the SCC significantly rose with the subject's age. Although SCC difference was not significant and the patterns appeared similar for both the considered breeds, the Nera Verzasca goat had a lower SCC than the Alpine goat when considering the breed, DIM class and age class. These data showed that the Verzasca breed can maintain lower levels of mastitis maker, suggesting a better resistance against the mammary gland pathogen. This breed has already shown interesting traits regarding the resistance against pathogens, especially concerning gastrointestinal parasites [34,35].

The fat/protein ratio was considered a valuable variable to monitor the nutrient balance [22], mainly in early postpartum; Heuer et al. and Toni et al. report that the fat/protein ratio is, in cattle, a reliable predictor for several diseases, fertility problems and variation in milk yield $[22,36]$. Toni et al. refer that cows with a higher milk fat/protein ratio (over than 1.5) have a higher probability of disease and culling [22]. Sandrucci et al. evaluated the milk fat/protein ratio also in goats and resulted significantly influenced by the month of kidding, stage of lactation, herd size, parity and milk production volume [9]. Our data suggest a parallelism of the fat/protein ratio behavior; among examined goats, the Alpine subjects had a fat/protein ratio above 1.5, making difficult an evaluation of the phenomenon, considering that the cutoff was established for the bovine species.

Another interesting parameter to evaluate the energy balance was the fat/lactose ratio in milk which was indicated in cattle as a valid indicator for mastitis and ketosis $[23,37]$. Our data showed an increased ratio for both breeds around the 31-50 days in milk, which was the period associated with the most elevated energy requirement necessary to cope with the elevated milk yield. Another peak was visible at the end of the lactation; this was due to the physiological reduction in lactose associated with the moderate elevation of fat which was physiological at the end of lactation [37,38].

Correlations between milk traits in Alpine goats vary in literature; Zeng et al. report a lower fat/lactose correlation with respect to our results ( $\mathrm{r}=0.14$ vs. 0.41 , respectively) [25]. Protein/lactose correlation is sensibly higher in the data referred by Zeng et al. compared 
to our results ( $\mathrm{r}=0.25$ vs. 0.02 , respectively) [25]. Additionally, the protein/SCC and protein/milk yield correlations in our samples were sensibly higher than those reported by Zeng et al. (protein $/$ SCC correlation $\mathrm{r}=0.17 \mathrm{vs}$. 0.27 and protein $/ \mathrm{milk}$ yield correlation $\mathrm{r}=0.04$ vs. -0.31 in Zeng et al. data and our samples, respectively) [25]. The SCC / milk yield correlation differs between results reported by Zeng et al. and our data $(\mathrm{r}=-0.09$ vs. -0.40 , respectively) [25]. These correlations appeared overall stronger in our data; this could be due to different management methods and different feeding systems from the standing point of each breed. However, also the study by Mioč et al. investigated the same correlation and shows many results in agreement with ours [26]. In particular, the positive correlation between the milk yield and lactose could be due to the osmotic activity of the latter, which is responsible for a higher milk production when present at higher concentrations. Obviously, because of a sort of dilution effect, milk yield was negatively correlated with the fat percentage, protein percentage and SCC.

\section{Conclusions}

The Nera di Verzasca goat, a local breed in Northern Italy, had overall lactation characteristics similar to a cosmopolite breed such as Alpine, with the exception of the milk daily yield reduced with respect to Alpine goats. These aspects can be taken into account in further research to study the motivations of these discrepancies and the effects of these features on the milk transformation. Moreover, these findings are important in the optic of biodiversity conservation; despite their lower production, local breeds could play a key role in the future, thanks to the ability to guarantee, also in marginal areas, products with a high level of quality and safety, along with a plethora of ecosystem services.

Author Contributions: Conceptualization, S.A., G.C. and M.F.; methodology, S.A., G.C. and M.F.; software, M.F.; formal analysis, M.F.; resources, D.V.; data curation, M.F.; writing-original draft preparation, S.A., A.L.G., G.C., M.F., S.D., G.B., D.V., M.T.M., S.A.Z., L.P., M.S., A.M., M.C. and L.M.; writing-review and editing, S.A., G.C.; visualization, G.B.; supervision, G.B. and D.V.; project administration, G.B., D.V. and M.T.M.; funding acquisition, D.V. and M.T.M. All authors have read and agreed to the published version of the manuscript.

Funding: This research received no external funding.

Institutional Review Board Statement: The collections of biological samples from live animals were performed in respect of animal welfare according to the current legislation, approved by the Institutional Animal Care and Use Committee of Università degli Studi di Milano (Permission OPBA_34_2013).

Informed Consent Statement: Not applicable.

Conflicts of Interest: The authors declare no conflict of interest.

\section{References}

1. Zheng, Z.; Wang, X.; Li, M.; Li, Y.; Yang, Z.; Wang, X.; Pan, X.; Gong, M.; Zhang, Y.; Guo, Y.; et al. The origin of domestication genes in goats. Sci. Adv. 2020, 6, eaaz5216. [CrossRef]

2. FAO FAOSTAT. Food and Agriculture Organization of the United Nations. 2020. Available online: http://www.fao.org/faostat/ en/\#data/QA (accessed on 4 July 2021).

3. Castrica, M.; Ventura, V.; Panseri, S.; Ferrazzi, G.; Tedesco, D.; Balzaretti, C.M. The sustainability of urban food systems: The case of mozzarella production in the city of Milan. Sustainability 2020, 12, 682. [CrossRef]

4. Miller, B.A.; Lu, C.D. Current status of global dairy goat production: An overview. Asian-Australas. J. Anim. Sci. 2019, 32, 1219-1232. [CrossRef]

5. Park, Y.W.; Haenlein, G.F.W.; Wendorff, W.L. Handbook of Milk of Non-Bovine Mammals, 2nd ed.; John Wiley \& Sons Ltd.: Hoboken, NJ, USA, 2017; ISBN 9781119110279.

6. Haenlein, G.F.W. Goat milk in human nutrition. Small Rumin. Res. 2004, 51, 155-163. [CrossRef]

7. Ballabio, C.; Chessa, S.; Rignanese, D.; Gigliotti, C.; Pagnacco, G.; Terracciano, L.; Fiocchi, A.; Restani, P.; Caroli, A.M. Goat milk allergenicity as a function of $\alpha$ S1-casein genetic polymorphism. J. Dairy Sci. 2011, 94, 998-1004. [CrossRef]

8. ISTAT. Available online: https:/ / www.istat.it/ (accessed on 4 July 2021).

9. Sandrucci, A.; Bava, L.; Tamburini, A.; Gislon, G.; Zucali, M. Management practices and milk quality in dairy goat farms in Northern Italy. Ital. J. Anim. Sci. 2019, 18, 1-12. [CrossRef] 
10. Agradi, S.; Curone, G.; Negroni, D.; Vigo, D.; Brecchia, G.; Bronzo, V.; Panseri, S.; Chiesa, L.M.; Peric, T.; Danes, D.; et al. Determination of fatty acids profile in original brown cows dairy products and relationship with alpine pasture farming system. Animals 2020, 10, 1231. [CrossRef]

11. Claps, S.; Di Napoli, M.A.; Sepe, L.; Caputo, A.R.; Rufrano, D.; Di Trana, A.; Annicchiarico, G.; Fedele, V. Sialyloligosaccharides content in colostrum and milk of two goat breeds. Small Rumin. Res. 2014, 121, 116-119. [CrossRef]

12. Currò, S.; Manuelian, C.L.; De Marchi, M.; De Palo, P.; Claps, S.; Maggiolino, A.; Campanile, G.; Rufrano, D.; Fontana, A.; Pedota, G.; et al. Autochthonous dairy goat breeds showed better milk quality than Saanen under the same environmental conditions. Arch. Anim. Breed. 2019, 62, 83-89. [CrossRef]

13. Currò, S.; Manuelian, C.L.; De Marchi, M.; Goi, A.; Claps, S.; Esposito, L.; Neglia, G. Italian local goat breeds have better milk coagulation properties than cosmopolitan breed. Ital. J. Anim. Sci. 2020, 19, 593-601. [CrossRef]

14. Manuelian, C.L.; Maggiolino, A.; De Marchi, M.; Claps, S.; Esposito, L.; Rufrano, D.; Casalino, E.; Tateo, A.; Neglia, G.; De Palo, P. Comparison of mineral, metabolic, and oxidative profile of saanen goat during lactation with different mediterranean breed clusters under the same environmental conditions. Animals 2020, 10, 432. [CrossRef]

15. Tripaldi, C.; Martillotti, F.; Terramoccia, S. Content of taurine and other free amino acids in milk of goats bred in Italy. Small Rumin. Res. 1998, 30, 127-136. [CrossRef]

16. Currò, S.; Manuelian, C.L.; De Marchi, M.; Claps, S.; Rufrano, D.; Neglia, G. Effects of breed and stage of lactation on milk fatty acid composition of Italian goat breeds. Animals 2019, 9, 764. [CrossRef]

17. Vacca, G.M.; Stocco, G.; Dettori, M.L.; Pira, E.; Bittante, G.; Pazzola, M. Milk yield, quality, and coagulation properties of 6 breeds of goats: Environmental and individual variability. J. Dairy Sci. 2018, 101, 7236-7247. [CrossRef] [PubMed]

18. Claps, S.; Di Napoli, M.A.; Caputo, A.R.; Rufrano, D.; Sepe, L.; Di Trana, A. Factor affecting the 3' sialyllactose, 6' sialyllactose and disialyllactose content in caprine colostrum and milk: Breed and parity. Small Rumin. Res. 2016, 134, 8-13. [CrossRef]

19. Vacca, G.M.; Stocco, G.; Dettori, M.L.; Summer, A.; Cipolat-Gotet, C.; Bittante, G.; Pazzola, M. Cheese yield, cheesemaking efficiency, and daily production of 6 breeds of goats. J. Dairy Sci. 2018, 101, 7817-7832. [CrossRef]

20. Maggioni, L.; Mondellini, N.; Corti, M. Utilizzazione di formazioni vegetali miste nelle Prealpi lombarde occidentali mediante circuiti di pascolo con capre da latte. In II Sistema delle Malghe Alpine: Aspetti Agro-Zootecnici, Paesaggistici e Turistici; SoZooAlp: San Michele All'adige, Italy, 2004; Volume 1, pp. 139-147.

21. International Agreement of Recording Practices, Guidelines Approved by the General Assembly. In Proceedings of the International Committee for Animal Recording-ICAR, Niagara Falls, NY, USA, 18 June 2008.

22. Toni, F.; Vincenti, L.; Grigoletto, L.; Ricci, A.; Schukken, Y.H. Early lactation ratio of fat and protein percentage in milk is associated with health, milk production, and survival. J. Dairy Sci. 2011, 94, 1772-1783. [CrossRef] [PubMed]

23. Paudyal, S.; Maunsell, F.P.; Risco, C.A.; Donovan, A.; De Vries, A.; Manriquez, D.; Pinedo, P.J. Evaluating milk fat to protein ratio and milk fat to lactose ratio as indicators for early lactation disease. J. Anim. Sci. 2016, 94, 69-70. [CrossRef]

24. Jarosz, A.F.; Wiley, J. What Are the Odds? A Practical Guide to Computing and Reporting Bayes Factors. J. Probl. Solving 2014, 7, 2-9. [CrossRef]

25. Zeng, S.S.; Escobar, E.N.; Popham, T. Daily variations in somatic cell count, composition, and production of Alpine goat milk. Small Rumin. Res. 1997, 26, 253-260. [CrossRef]

26. Piliena, K.; Jonkus, D. Factors affecting goat milk yield and its composition in Latvia. Res. Rural Dev. 2012, 1, 79-84.

27. Špehar, M.; Mulc, D.; Barać, Z.; Mioč, B.; Kasap, A. Estimation of genetic parameters for dairy traits using repeatability animal models based on test-day data for alpine goat in croatia. Mljekarstvo 2019, 69, 215-221. [CrossRef]

28. Salvador, A.; Martínez, G. Factores que afectan la producción y composición de la leche de cabra: Revisión bibliográfica. Rev. Fac. Cienc. Vet. UCV 2007, 48, 61-76.

29. Crepaldi, P.; Corti, M.; Cicogna, M. Factors affecting milk production and prolificacy of Alpine goats in Lombardy (Italy). Small Rumin. Res. 1999, 32, 83-88. [CrossRef]

30. Zeng, S.S.; Escobar, E.N. Effect of breed and milking method on somatic cell count, standard plate count and composition of goat milk. Small Rumin. Res. 1996, 19, 169-175. [CrossRef]

31. Antunac, N.; Samaržija, D.; Havranek, J.L.; Pavić, V.; Mioć, B. Effects of stage and number of lactation on the chemical composition of goat milk. Czech J. Anim. Sci. 2001, 46, 548-553.

32. Paape, M.J.; Poutrel, B.; Contreras, A.; Marco, J.C.; Capuco, A.V. Milk Somatic Cells and Lactation in Small Ruminants. J. Dairy Sci. 2001, 84, E237-E244. [CrossRef]

33. Tedde, V.; Bronzo, V.; Puggioni, G.M.G.; Pollera, C.; Casula, A.; Curone, G.; Moroni, P.; Uzzau, S.; Addis, M.F. Milk cathelicidin and somatic cell counts in dairy goats along the course of lactation. J. Dairy Res. 2019, 86, 217-221. [CrossRef]

34. Zanzani, S.A.; Gazzonis, A.L.; Alberti, E.; Neilly, T.M.; Villa, L.; Manfredi, M.T. Gastrointestinal nematode infections in goats: Differences between strongyle faecal egg counts and specific antibody responses to Teladorsagia circumcincta in Nera di Verzasca and Alpine goats. Parasitol. Res. 2020, 119, 2539-2548. [CrossRef]

35. Gazzonis, A.L.; Zanazni, S.A.; Giuliani, G.; Alberti, E.; Villa, L.; Manfredi, M.T. Comparison of Naturally Occurring Eimeria Infections in Alpine and Nera Di Verzasca Goat Breeds Reared in a Sub-Alpine Environment. J. Parasitol. 2021, 107, $463-471$. [CrossRef] [PubMed]

36. Heuer, C.; Schukken, Y.H.; Dobbelaar, P. Postpartum body condition score and results from the first test day milk as predictors of disease, fertility, yield, and culling in commercial dairy herds. J. Dairy Sci. 1999, 82, 295-304. [CrossRef] 
37. Reist, M.; Erdin, D.; von Euw, D.; Tschuemperlin, K.; Leuenberger, H.; Chilliard, Y.; Hammon, H.M.; Morel, C.; Philipona, C.; Zbinden, Y.; et al. Estimation of Energy Balance at the Individual and Herd Level Using Blood and Milk Traits in High-Yielding Dairy Cows. J. Dairy Sci. 2002, 85, 3314-3327. [CrossRef]

38. Fekadu, B.; Soryal, K.; Zeng, S.; Van Hekken, D.; Bah, B.; Villaquiran, M. Changes in goat milk composition during lactation and their effect on yield and quality of hard and semi-hard cheeses. Small Rumin. Res. 2005, 59, 55-63. [CrossRef] 